http://ejurnal.ubharajaya.ac.id/index.php/EDUKARYA

\title{
Peningkatan Hasil Belajar Melalui Penerapan Media PowerPoint pada Tema Pertumbuhan dan Perkembangan Makhluk Hidup
}

\author{
Asri Kurnia ${ }^{1 *}$, Nunuy Nurkaeti ${ }^{2}$ \\ ${ }^{1}$ SDN Burujul Kulon I, Dinas Pendidikan Majalengka, Jl. Dusun Ciporang Desa Burujul Kulon \\ Jatiwangi Kabupaten Majalengka 45454, Indonesia \\ ${ }^{2}$ Pendidikan Guru Sekolah Dasar, Fakultas Ilmu Pendidikan, Universitas Bhayangkara Jakarta \\ Raya, Jl. Raya Perjuangan No. 81, Bekasi 17142, Indonesia \\ e-mail: ${ }^{1}$ asrikurnia13@ gmail.com, ${ }^{2}$ nunuy.nurkaeti@dsn.ubharajaya.ac.id \\ *Korespondensi e-mail: asrikurnia13@gmail.com
}

\begin{abstract}
Based on preliminary studies conducted at SDN Pengadilan 2 Kota Bogor that study with the curriculum 2013 includes aspects of the attitudes, knowledge, and still needs development and improvement of learning processes and outcomes. This study aims to improve the process and student learning outcomes through the application of powerpoint media. This research method is a classroom action research that refers to the Kemmis and Taggart design with a sample of 26 third grade students of SDN Pengadilan 2 Bogor City. Preliminary data on student learning outcomes show that only 7.69\% of students achieved the Minimum Mastery Criteria (KKM). The results showed an increase in the average learning process by $91.73 \%$ (cycle I) to $95.02 \%$ (cycle II) with very good interpretation. Improved learning process followed by an increase in learning outcomes includes an increase in the average spiritual attitude, social, knowledge, and skills with very good interpretation. It is show that the learning with using powerpoint media could improve the process and learning outcomes.
\end{abstract}

Keywords : Media Slides PowerPoint, Learning Outcomes, and KKM.

\begin{abstract}
Abstrak
Berdasarkan studi pendahuluan yang dilakukan di SDN Pengadilan 2 Kota Bogor hasil belajar peserta didik dengan menggunakan kurikulum 2013 mencakup aspek sikap, pengetahuan, dan keterampilan masih membutuhkan pengembangan dan peningkatan proses dan hasil belajar. Penelitian ini bertujuan untuk memperbaiki proses dan hasil belajar peserta didik melalui penerapan media power point. Metode penelitian ini adalah penelitian tindakan kelas yang mengacu kepada desain Kemmis dan Taggart dengan sampel 26 orang peserta didik kelas III SDN Pengadilan 2 Kota Bogor. Data awal hasil belajar peserta didik menunjukkan hanya 7,69\% peserta didik yang mencapai Kriteria Ketuntasan Minimal (KKM). Hasil penelitian menunjukkan peningkatan rata-rata proses pembelajaran sebesar 91,73\% (siklus I) menjadi 95,02\% (siklus II) dengan interpretasi sangat baik. Peningkatan proses belajar diikuti dengan adanya peningkatan hasil belajar mencakup peningkatan rata-rata sikap spiritual, social, pengetahuan, dan keterampilan dengan interpretasi sangat baik. Ini menunjukkan bahwa pembelajaran yang dilakukan dengan penggunaan media powerpoint dapat memperbaiki proses dan hasil belajar.
\end{abstract}

Kata Kunci: Media PowerPoint, Hasil Belajar, dan KKM.

\section{PENDAHULUAN}

Kurikulum yang dilaksanankan pada tahun pelajaran 2018/2019 semester ganjil pada jenjang pendidikan baik dasar, menengah atau pun tinggi yaitu kurikulum 2013. Dalam kurikulum 2013 inilah pembelajaran mulai terintegrasi dari beberapa muatan pembelajaran. Artinya, pembelajaran tidak lagi terbagi-bagi menjadi muatan pelajaran yang diketahui peserta didik seperti PPKn, Bahasa Indonesia, Matematika dan yang lainnya seperti pada kurikulum yang sebelumnya melainkan dalam sehari pembelajaran dilakukan dengan tematik. Pembelajaran tematik yaitu pembelajaran yang mengemas 
materi menjadi sebuah tema serta melibatkan keaktifan peserta didik dan kemandirian yang disajikan lebih dekat dengan dunia nyata peserta didik. Oleh karena itu, membelajarkan peserta didik harus lebih berinovasi.

Pada hakikatnya, belajar yang dilakukan peserta didik adalah suatu rangkaian berfikir yang melibatkan berbagai komponen diantaranya adalah lingkungan. Lingkungan adalah suatu bahan ajar yang sangat penting mengingat manfaat lingkungan memberikan dampak positif dalam menghasilkan suatu pengajaran yang efektif. Namun, kurangnya pemanfaatan fasilitas dan sarana sekolah selalu menjadi kendala. Para guru pada umumnya menyajikan pembelajaran secara abstrak dan terpaku akan buku yang telah ada sehingga meningalkan pentingnya interaksi lingkungan sebagaimana yang dibutuhkan oleh peserta didik. Rahmattullah (2011) mengemukakan guru banyak yang terpaku pada penggunaan buku paket sehingga kurangnya perhatian siswa dalam pembelajaran. Jika dilihat, fasilitas sarana dan prasarana sekolah bisa dimanfaatkan dengan baik misalnya tiang, pohon kering, dedaunan, barang bekas bahkan kemampuan guru yang ditunjang dengan keahliannya seperti internet dan gadget. Macam-macam objek tersebut dapat digunakan oleh guru untuk memecahkan masalah pembelajaran agar interaksi peserta didik dengan lingkungan belajar dapat dilakukan dengan baik. Peserta didik pun akan lebih cepat merasakan manfaat belajar untuk kehidupannya. Namun pemanfaatan fasilitas sarana dan prasarana tersebut masih belum optimal terutama kaitannya dengan penggunaan teknologi sederhananya penggunaan computer dan internet. Seperti yang dikemukakan Riskiawan, Setyohadi, \& Arifianto (2016) guru masih kurang dalam pemanfaatan teknologi informasi dalam pembelajaran.

Fakta yang berpengaruh terhadap keberhasilan belajar peserta didik jelas tergambar yaitu media pembelajaran untuk menciptakan lingkungan belajar peserta didik yang menyenangkan. Widodo (2016) mengemukakan salah satu hal yang mendorong terciptanya pembelajaran menyenangkan dan bermakna adalah adanya penggunaan pendekatan saintifik, humor dalam pembelajaran, pembelajaran kelompok, serta pengorganisasian materi yang tepat. Pengorganisasian materi akan tepat jika menggunakan media pembelajatan yang efektif dan efisien, salah satunya menggunakan PowerPoint. Menurut Surachman (2016) penggaorganisasian materi pelajaran menggunakan media PowerPoint dapat menjadi alternative bagi guru dalam menyajikan pembelajarn yang menarik dan menyenangkan dengan adanya pemanfaatan teknologi tersebut. Media pembelajaran merupakan perantara terjadinya komunikasi yang baik dan menyenangkan antara guru dengan peserta didik. Semangat belajar peserta didik akan menyenangkan manakala guru membawakan pembelajaran dengan media disetiap pembelajarannya. Kemampuan guru dalam membuat media menjadikan hal penting dalam keberhasilan proses pembelajaran di kelas.

Pada kurikulum 2013 hasil belajar ditekankan pada aspek sikap, keterampilan, dan pengetahuan. Berdasarkan pengambilan data awal (pretest) aspek pengetahuan peserta didik menunjukan hasil yang kurang baik dari 26 peserta didik, yang mendapat nilai 83 sebanyak 2 orang $(7,69 \%)$, nilai 80 sebanyak 6 orang $(23,08 \%)$, nilai 73 sebanyak 3 orang $(11,54 \%)$, nilai 71 sebanyak 1 orang $(3,85 \%)$, nilai 70 sebanyak 5 orang $(19,23 \%)$, nilai 69 sebanyak 3 orang $(11,54 \%)$, dan nilai 68 sebanyak 6 orang $(23,08 \%)$. Hasil belajar peserta didik sebanyak 26 orang di atas dapat disimpulkan bahwa hanya 8 orang $(7,69 \%)$ yang memenuhi kriteria ketuntasan minimum (KKM) bahasa Indonesia yaitu sebesar 79 . Sementara sisanya 18 orang $(69,23 \%)$ belum dapat memenuhi Kriteria Ketuntasan Minimal (KKM).

Berdasarkan pandangan peneliti, guru tidak menggunakan media yang dapat 
memasilitasi keragaam materi yang ada dalam kurikulum 2013 yang kompleks karena semua mata pelajaran terintergasi. Berdasarkan hal tersebut, diperlukan suatu tindakan agar dapat mengatasi permasalahan yang terjadi dalam pembelajaran, sehingga terjadi peningkatan dalam hasil belajar peserta didik. Dari beberapa alternatif yang ada, peneliti mengambil tindakan yang sesuai dengan mengemas penggunaan media powerpoint yang memiliki kelebihan diantaranya mengemas semua materi dalam satu media. Menurut Nursalim (2013, hlm. 74) program powerpoint merupakan salah satu software yang dirancang khusus untuk mampu menampilkan program multimedia dengan menarik, mudah dalam pembuatan, mudah dalam penggunaan, dan relatif murah, karena tidak membutuhkan bahan baku selain alat untuk penyimpanan data (data storage). Media ini menampilkan slide gambar, video, dan beberpa kombinasi animasi, warna, teks, dan permainan sehingga peserta didik akan terfasilitasi dalam belajar secara langsung dan konkret. Melalui Model dan media ini diharapkan hasil belajar peserta didik mengalami peningkatan dan pembelajaran menjadi lebih bermakna. Berdasarkan hal tersebut penelitian ini berjudul "Peningkatan Hasil Belajar Melalui Penerapan Media PowerPoint pada Tema Pertumbuhan dan Perkembangan Makhluk Hidup" untuk mengetahui penerapan media PowerPoint dalam meningkatkan proses dan hasil belajar peserta didik.

\section{METODE PENELITIAN}

Desain penelitian yang digunakan dalam penelitian ini adalah desain penelitian tindakan kelas dengan prosedur berupa siklus. Siklus tersebut berupa tindakan yang akan berlangsung dalam beberapa tahap. Hal ini bergantung dari tingkat keberhasilan dari target yang akan dicapai. Setiap siklus dilakukan dalam dua kali tindakan.

Prosedur penelitian yang dipilih yaitu menggunakan model spiral dari Kemmis dan Taggart prosedur penelitian ini mengandung empat konsep pokok action research meliputi; perencanaan (planning), aksi/tindakan (action), observasi (observing), dan refleksi (reflecting). Lebih jelas Hanifah (2014, hlm. 31) menggambarkan sebagai berikut.

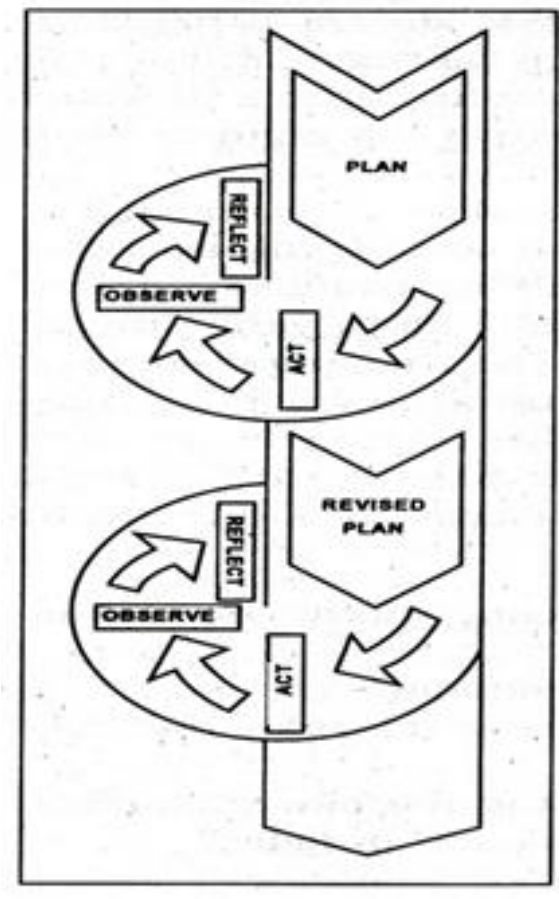

Gambar 1. Desain PTK Model Spiral dari Kemmis dan Taggart 
Penelitian ini dilaksanakan di kelas III-B SD Negeri Pengadilan 2 Kota Bogor, dengan jumlah peserta didik 26 orang yang terdiri dari 10 peserta didik laki-laki dan 16 peserta didik perempuan sebagai subjek peningkatan hasil belajar tema 1 yaitu pertumbuahan dan perkembangan makhluk hidup.

Penelitian ini dianggap berhasil apabila:

1. Indikator perencanaan pembelajaran minimal baik.

2. perbaikan proses pembelajaran minimal baik.

3. Indikator sikap (sikap spiritual dan sosial) peserta didik minimal baik.

4. Indikator keterampilan peserta didik minimal baik.

5. Indikator kinerja atau ketuntasan hasil belajar belajar secara klasikal minimal $85 \%$ dari jumlah peserta didik mencapai KKM sebesar yang ditentukan.

\section{HASIL DAN PEMBAHASAN}

Pada kondisi prasiklus sebelum penggunan media PowerPoint di kelas III Sekolah Dasar Negeri Pengadilan Bogor dengan tema pertumbuhan dan perkembangan makhluk hidup, ada beberapa aspek yang peneliti lakukan diantaranya, kinerja guru, aktivitas peserta didik dan hasil belajar aspek pengetahuan didapat hasil sebagai berikut ini.

1. Kinerja guru

Secara keseluruhan gambaran kinerja guru saat prasiklus dapat dilihat pada Tabel 1 berikut ini.

Tabel 1. Data Observasi Awal Kinerja Guru

\begin{tabular}{|c|c|c|c|c|c|}
\hline \multirow{2}{*}{ NO } & \multirow{2}{*}{ Aspek yang Diamati } & \multicolumn{4}{|c|}{ Skor } \\
\hline & & 0 & 1 & 2 & 3 \\
\hline A & PERENCANAAN & & & & \\
\hline 1. & Mempersiapkan RPP & & $\sqrt{ }$ & & \\
\hline 2 & Mempersiapkan LKS & & $\sqrt{ }$ & & \\
\hline 3 & Mempersiapkan Lembar penilaian & $\sqrt{ }$ & & & \\
\hline 4 & Mempersiapkan Bahan Ajar & & & $\sqrt{ }$ & \\
\hline & Jumlah Skor & & & & \\
\hline & $\begin{array}{c}\text { Persentase \% } \\
\text { Kriteria }\end{array}$ & & & & \\
\hline $\mathrm{B}$ & PELAKSANAAN & & & & \\
\hline 1 & Mengkondisikan Peserta didik & & & & $\sqrt{ }$ \\
\hline 2 & Mengadakan Apersepsi & & & $\sqrt{ }$ & \\
\hline 3 & Menyampaikan Tujuan Pembelajaran & & $\sqrt{ }$ & & \\
\hline 4 & Penguasaan Materi Pembelajaran & & & & $\sqrt{ }$ \\
\hline 5 & $\begin{array}{l}\text { Penerapan Pendeketan/ Strategi } \\
\text { Pembelajaran }\end{array}$ & $\sqrt{ }$ & & & \\
\hline 6 & $\begin{array}{l}\text { Pemanfaatan Media Pembelajaran/ } \\
\text { Sumber Belajar }\end{array}$ & $\sqrt{ }$ & & & \\
\hline 7 & $\begin{array}{l}\text { Pembelajaran yang Memicu dan } \\
\text { Memelihara Keterlibatan Peserta didik }\end{array}$ & & $\sqrt{ }$ & & \\
\hline 8 & Menyimpulkan pembelajaran & & $\sqrt{ }$ & & \\
\hline 9 & Evaluasi & & $\sqrt{ }$ & & \\
\hline & $\begin{array}{c}\text { Jumlah Skor } \\
\text { Persentase } \\
\text { Kriteria }\end{array}$ & & & $\begin{array}{l}\% \\
\text { ang }\end{array}$ & \\
\hline
\end{tabular}




\section{Aktivitas peserta didik}

Pada saat mengikuti proses pembelajaran terlihat ada yang bermain dengan temannya. Mereka cenderung kurang memperhatikan materi yang diajarkan oleh guru. Kurangnya penekanan terhadap materi dan prosedur pembelajaran membuat peserta didik semakin kesulitan untuk mengekplorasi dan memahami pelajaran yang diberikan guru. Peserta didik banyak yang kebingungan dan tak sedikit juga yang melamun yang menyebabkan rendahnya aktivitas peserta didik dalam pembelajaran. Ketika guru memberikan latihan soal yang ada di buku paket atau buku sumber, banyak peserta didik yang menanyakan jawaban kepada guru dan banyak peserta didik yang kesulitan mengerjakan soal yang ada dalam buku.

3. Hasil belajar

Data hasil belajar diperoleh melalui tes awal terhadap peserta didik kelas III-B SD Negeri Pengadilan 2 Kota Bogor secara lebih rinci dapat sebagai berikut.

Tabel 2. Data Awal Hasil Belajar Aspek Pengetahuan

\begin{tabular}{ccc}
\hline \multicolumn{2}{c}{ Kriteria } & Jumlah \\
Tuntas & Belum tuntas & \\
\hline 8 orang & 18 orang & 26 Orang \\
$30,8 \%$ & $69,2 \%$ & $100 \%$ \\
\hline
\end{tabular}

Dari Tabel 2 mengenai pencapaian hasil belajar diperoleh data hanya delapan peserta didik yang nilainnya dapat mencapai nilai KKM yang telah ditentukan yaitu 79, sedangkan 18 peserta didik lainnya masih dibawah nilai KKM. Melihat kondisi tersebut pembelajaran yang telah berlangsung masih belum optimal karena baru 30,8\% yang dapat mencapai nilai KKM, sedangkan 69,2\% belum dapat mencapai nilai KKM. Lebih jelas digambakan dalan diagram berikut ini.

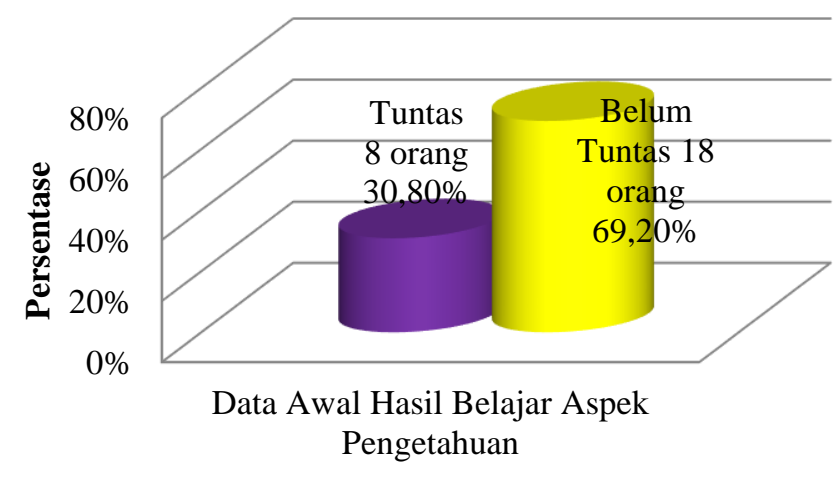

Gambar 2. Diagram Batang Data Awal Hasil Belajar Aspek Pengetahuan

Selanjutnya dilakukan penelitian tindakan di peroleh perbandingan hasil dari siklus I dan siklus II dengan rekapitulasi sebagai berikut. 
Tabel 3. Rekapitulasi Hasil Penelitian Siklus I dan II

\begin{tabular}{|c|c|c|c|c|c|}
\hline \multirow{2}{*}{$\begin{array}{l}\text { Aspek yang } \\
\text { diteliti }\end{array}$} & \multirow[b]{2}{*}{$\begin{array}{c}\text { Siklus } \\
\text { I }\end{array}$} & \multicolumn{2}{|c|}{$\begin{array}{c}\text { Hasil Siklus } \\
\text { Rata-rata }\end{array}$} & \multirow[b]{2}{*}{ Interpretasi } & \multirow{2}{*}{ Keterangan } \\
\hline & & Interpretasi & $\begin{array}{c}\text { Siklus } \\
\text { II }\end{array}$ & & \\
\hline $\begin{array}{c}\text { Perencanaan } \\
\text { Pembelajaran }\end{array}$ & 90,63 & $\begin{array}{l}\text { Sangat } \\
\text { Baik }\end{array}$ & 95,05 & $\begin{array}{l}\text { Sangat } \\
\text { Baik }\end{array}$ & $\begin{array}{c}\text { Terdapat } \\
\text { kenaikan } \\
\text { nilai sebesar } \\
4,42 . \\
\text { Ter. }\end{array}$ \\
\hline $\begin{array}{c}\text { Proses } \\
\text { Pembelajaran }\end{array}$ & 91,73 & $\begin{array}{l}\text { Sangat } \\
\text { Baik }\end{array}$ & 95,02 & $\begin{array}{l}\text { Sangat } \\
\text { Baik }\end{array}$ & $\begin{array}{c}\text { Terdapat } \\
\text { kenaikan } \\
\text { nilai sebesar } \\
3,29 .\end{array}$ \\
\hline $\begin{array}{c}\text { Aktivitas } \\
\text { peserta didik } \\
\text { (Off Task dan } \\
\text { On Task) }\end{array}$ & $83 \%$ & - & $93,5 \%$ & - & $\begin{array}{c}\text { Terdapat } \\
\text { kenaikan } \\
\text { sebesar } \\
10,5 \%\end{array}$ \\
\hline $\begin{array}{l}\text { Hasil belajar } \\
\text { aspek sikap } \\
\text { spiritual }\end{array}$ & 79,70 & Baik & 82,02 & $\begin{array}{l}\text { Sangat } \\
\text { Baik }\end{array}$ & $\begin{array}{c}\text { Terdapat } \\
\text { kenaikan } \\
\text { nilai sebesar } \\
2,32 .\end{array}$ \\
\hline $\begin{array}{c}\text { Hasil belajar } \\
\text { aspek sikap } \\
\text { sosial }\end{array}$ & 66,25 & Baik & 71,79 & Baik & $\begin{array}{c}\text { Terdapat } \\
\text { kenaikan } \\
\text { nilai sebesar } \\
5,54 .\end{array}$ \\
\hline $\begin{array}{l}\text { Hasil belajar } \\
\text { aspek } \\
\text { keterampilan }\end{array}$ & 53,74 & Cukup & 82,79 & $\begin{array}{l}\text { Sangat } \\
\text { Baik }\end{array}$ & $\begin{array}{c}\text { Terdapat } \\
\text { kenaikan } \\
\text { nilai sebesar } \\
29,05 .\end{array}$ \\
\hline $\begin{array}{l}\text { hasil belajar } \\
\text { aspek } \\
\text { pengetahuan }\end{array}$ & $62 \%$ & $\begin{array}{l}\text { Belum } \\
\text { Tuntas }\end{array}$ & $89 \%$ & Tuntas & $\begin{array}{c}\text { Terdapat } \\
\text { kenaikan } \\
\text { sebesar } \\
27 \% \text {. }\end{array}$ \\
\hline $\begin{array}{c}\text { Nilai rata-rata } \\
\text { aspek } \\
\text { pengetahuan }\end{array}$ & 75,96 & $\begin{array}{l}\text { Belum } \\
\text { Tuntas }\end{array}$ & 83,12 & Tuntas & $\begin{array}{c}\text { Terdapat } \\
\text { kenaikan } \\
\text { sebesar } \\
7,17 .\end{array}$ \\
\hline
\end{tabular}

Telah disebutkan di atas bahwa penelitian diangap berhasil jika indikator perencanaan pembelajaran, perbaikan proses pembelajaran, sikap (sikap spiritual dan sosial), keterampilan peserta didik minimal baik, serta ketuntasan hasil belajar belajar secara klasikal minimal 85\% dari jumlah peserta didik mencapai KKM sebesar yang ditentukan yaitu 79. Maka dari itu, berdasarkan tabel diatas dapat dikatakan bahwa seluruh indikator penelitian dapat terpenuhi, berikut pembahasannya.

a. Perencanaan Pembelajaran

Berdasarkan refleksi pada siklus sebelumnya, pada siklus II dilakukan perbaikan terutama dalam hal yang kurang dalam catatan perencanaan yaitu dalam aspek 
pemilihan dan pengorganisasian materi, media dan sumber belajar. Setelah dilakukan tidakan diperolah nilai rata-rata perencanaan pada siklus II sebesar 95,05 dengan interpretasi sangat baik, nilai ini mengalami peningkatan sebesar 4,42 dari siklus sebelumnya. Hal tersebut juga telah menunjukan bahwa inditaor penelitian untuk tahap perencanaan telah tercapai dengan sangat baik.

b. Proses/Pelaksanaan Pembelajaran

Pelaksanaan pembelajaran siklus II merupakan perbaikan dari siklus I. Guru memperbaiki kekurangan dengan mengoftimalkan setiap langkah pembelajaran yaitu dalam tahap identifikasi, guru melibatkan peserta didik untuk membaca, mengamati, atau mendengarkan uraian yang memuat rangsangan belajar, serta guru memfasilitasi peserta didik dalam mengolah data serta melibatkan peserta didik dalam memanfaatkan media pembelajaran. Setelah diperbaiki nilai rata-rata pada siklus II 95,02 ini meningkat sebesar 3,29 dari siklus sebelumnya yaitu sebesar 91,73 . Hal ini menunjukan interpretasi yang sangat baik. begitu pula dengan aktivitas peserta didik yang di tunjukan dengan data on task sebesar 93,5\%.

c. Hasil belajar Aspek Sikap

Dilihat dari tabel diatas nilai rata-rata perubahan sikap spiritual mengalami peningkatan yaitu dari 79, 70 menjadi sebesar 82,02 dengan interpretasi sangat baik sedangkan nilai rata-rata sikap sosial dari 66,25 menjadi 71,79 dengan interpretasi baik. Hal ini berdasarkan perbaikan pembelajaran dari siklus I ke siklus II. Peserta didik mulai mampu mengucapkan rasa syukur dan mulai keberanian mengakui kesalahan. melalui pembiasaan dan aspek sikap yang baik yang guru selipkan dalam proses pembalajran. Peserta didik yang terlihat main-main pun mulai memeprhatikan guru dengan perbaikan media yang dibawa oleh guru. Peningatan yang diharapkan pun tercapai dengan baik.

d. Hasil belajar Aspek Keterampilan

Perbaikan pada aspek keterampilanpun dilakukan oleh guru melalui perbaikan di siklus II. Data awal menunjukan hasil sebesar 53,74 dengan kriteria cukup, naik menjadi 82,79 dengan kriteria sangat baik pada siklus II. Pengunaan huruf kapital, dan kalimat efektif dilakukan pada siklus II. Guru memfasilitasi peserta didik untuk menggunakan huruf sambung yang telah mereka kuasai. Sehingga hasil yang didapat pada kriteria pertama itu mengalami peningkatan. begitu pula dengan latihan membuat kalimat, satu persatu peserta didik mancoba mambuat kalimat di papan tulis tentang tahapan daur hidup tumbuhan. Hasilnya pun sangat memuaskan.

e. Hasil belajar Aspek Pengetahuan

Hasil belajar peserta didik pun menunjukan penigkatan dari 75,96 menjadi 83,12 yag artinya dari $62 \%$ di siklis I naik menjadi pada siklus ke II dari 26 peserta didik, sebanyak 23 orang atau $89 \%$ tuntas, sedangkan peserta didik yang belum tuntas yaitu sebesar 3 orang atau $11 \%$. Hal ini merupakan hasil perbaikan dari aktifias dan proses pembelajaran yang telah tersusun dengan baik serta peserta didik yang lebih aktif dan bertanggung jawab dalam belajar. Maka dari itu penelitian ini dikatakan telah memenuhi indikator penelitian sehingga penelitian dicukupkan sebanyak 2 siklus.

Penelitian ini telah berhasil meningkatkan hasil belajar tema pertumbuhan dan perkembangan makhluk hidup melalui penerapan media power point pada Peserta didik Kelas III-B di SD Negeri Pengadilan 2 Kecamatan Bogor Tengah Kota Bogor Semester Ganjil Tahun Pelajaran 2018/2019. Hasil penelitian menunjukan bahwa adanya peningkatan tersebut dikarenakan beberapa hal. Pertama berhasil atau tidak suatu 
pembelajaran tidak terlepas oleh peran guru dalam pelaksanaan pembelajaran dan faktor peserta itu sendiri. Hal ini sesuai dengan teori pembelajaran yang dikemukakan oleh ahli.

Beberapa ahli mendefinisikan media seperti Ibrahim (Daryanto, 2016, hlm. 4) menyatakan bahwa kata media merupakan bentuk jamak dari kata medium dimana medium dapat didefinisikan sebagai perantara atau pengantar terjadinya komunikasi dari pengirim menuju penerima". Berbeda hanya dengan Gerlach \& Ely (Arsyad, 2014, hlm. 3) menyatakan bahwa media apabila dipahami secara garis besar adalah manusia, materi atau kejadian yang membangun kondisi yang membuat peserta didik mampu memperoleh pengetahuan, keterampilan atau sikap. Sedangkan Daryanto (2012, hlm. 4) menyebutkan bahwa media pembelajaran merupakan sarana perantara yang digunakan sebagai alat dan bahan kegiatan dalam proses pembelajaran. Hal senada dikemukakan oleh Heinich (Musfiqon, 2012, hlm. 26) mendefinisikan media sebagai saluran informasi yang menghubungkan antara sumber informasi dan penerima.

Dari kelima pendapat ahli di atas dapat disimpulkan bahwa media pembelajaran adalah suatu alat dan bahan yang dapat digunakan sebagai perantara atau saluran informasi untuk membangun kondisi yang membuat peserta didik mampu memperolah sikap, pengatahuan, dan keterampilan. Media ini, memiliki beberapa macam jenis salahsatunya adalah media berbasis multimedia berupa PowerPoint. Menurut Noprianti \& Syarifuddin (2015, hlm. 5) menjelaskan bahwa slide adalah istilah yang dipakai untuk materi presentasi. Dalam rangka mengkomunikasikan informasi, biasanya komunikator akan dibantu oleh beberapa slide untuk presentasi baik itu berupa tabel ataupun gambar. Penggunaan slide ini dapat dibuat dalam perangkat lunak yang bernama PowerPoint. Amin (2013, hlm. 154) menyatakan bahwa tulisan dan gambar pada slide dapat dilihat dengan memasukkan ke dalam komputer dengan menggunakan program perangkat lunak PowerPoint.

Dapat disimpulkan bahwa media PowerPoint adalah perangkat lunak yang dapat menjadi perantara informasi untuk membangun kondisi yang membuat peserta didik mampu memperoleh sikap, pengetahuan, dan keterampilan melalui penyajikan beberapa komponen sekaligus seperti objek, teks, grafik, video, suara, tabel dan sebagainya dalam satu file untuk membantu peserta didik memahami materi pembelajaran dengan lebih nyata. Hal ini sejalan dengan hipotesis penelitian yang dikembangkan peneliti untuk memperkuat penelitian ini. Media terkini merupakan hal yang penting yang perlu dikembangkan terutama dalam memfasilitasi peserta didik. Ini terbukti dengan adanya perbaikan dari proses dan hasil pembelajaran. Hasil penelitian ini juga sejalan dengan penelitian yang telah dilakukan sebelumnya yaitu penelitian oleh Elpira \& Ghufron (2015) bahwa media pembelajaran PowerPoint dapat meningkatkan minat dan hasil belajar IPA peserta didik kelas IV sekolah dasar.

Hasil penelitian menunjukan bahwa terdapat pengaruh media PowerPoint terhadap minat belajar IPA peserta didik. Minat belajar peserta didik meningkat 13,77 atau 11,48\% yaitu hasil selisih rerataan sebelum pembelajaran 99,84 dengan hasil rerataan sesudah pembelajaran 113,61 . Sebagaimana penelitian yang dilakukan Werdhiana, Wahyono, \& Miftah (2020) bahwa penggunaan audio visual yang dikemas dalam media dalam PowerPoint mampu meningkatkan motivasi dan minat belajar siswa. Hasil belajarpun demikian yaitu mengalami peningkatan 14,01 atau $14,01 \%$ yaitu hasil selisih rarataan post-test 85,83 . Nilai rata-rata hasil belajar ilmu pengetahuan alam pada siklus I memperoleh nilai rata-rata $62,9 \%$ dengan presentase ketuntasan hasil belajar sebesar $70 \%$, pada siklus II nilai rata-rata diperoleh $70,1 \%$ dengan presentasi ketuntasan $87,5 \%$. Sedangkan kualitas pelaksanaan pembelajaran pada siklus I memperoleh nilai sebesar 
74,3\% dan di siklus II menjadi 94\%. Begitu pula dengan hasil observasi aktifitas peserta didik menunjukan adanya peningkatan dari siklus I sebesar $71 \%$ menjadi $90,5 \%$ di siklus II. Hasil observasi keterampilan peserta didikpun meningkat pada siklus I memperolah nilai $64,6 \%$ meningkat pada siklus II sebesar $84,5 \%$. Ini sejalan dengan penelitian Nurlatifah (2015) dan Asmadji (2013) bahwa penggunaan media PowerPoint dapat meningkatkan hasil belajar siswa dalam pembelajran IPA di sekolah dasar.

Dengan demikian penerapan media PowerPoint dapat meningkatkan hasil belajar tema pertumbuhan dan perkembangan makhluk hidup pada Peserta didik Kelas III-B di SD Negeri Pengadilan 2 Kecamatan Bogor Tengah Kota Bogor Semester Ganjil Tahun Pelajaran 2018/2019.

\section{SIMPULAN DAN REKOMENDASI}

Berdasarkan hasil penelitian yang telah dilakukan dapat disimpulkan bahwa penerapan media PowerPoint dapat memperbaiki proses pembelajaran pada tema pertumbuahan dan perkembangan makhluk hidup di kelas III-B SD Negeri Pengadilan 2 Kecamatan Bogor Tengah Kota Bogor semester ganjil tahun pelajaran 2018/2019. Hal ini sesuai peningkatan rata-rata proses pembelajaran pada siklus I sebesar $91,73 \%$ dan meningkat pada siklus II sebesar 95,02\% dengan interpretasi sangat baik. Selain itu, Penerapan media PowerPoint juga meningkatkan hasil belajar. Hal ini didasari oleh peningkatan rata-rata nilai sikap spiritual dari siklus I sebesar $79,70 \%$ meningkat menjadi $82,02 \%$ pada siklus II dengan interpretasi sangat baik. Sementara itu, peningkatan ratarata nilai sikap sosial dari siklus I sebesar $66,25 \%$ meningkat menjadi $71,79 \%$ pada siklus II dengan interpretasi baik. Begitupun dengan hasil belajar aspek keterampilan peningkatan rata-rata nilai keterampialan dari siklus I sebesar $53,74 \%$ meningkat menjadi $82,79 \%$ pada siklus II dengan interpretasi sangat baik, serta peningkatan hasil belajar aspek pengetahuan dengan persentase peserta didik yang telah mencpai KKM sebesar $62 \%$ pada siklus I dan meningkat menjadi $89 \%$ pada siklus II. Oleh karena itu, semua aspek dari indikator penelitian telah terpenuhi. Hasil penelitian ini dapat dijadikan rujukan bagi guru ataupun calon guru sebagai alternatif pemecahan masalah yang sama, dan semoga dapat dijadikan banding serta landasan penelitian lanjutan.

\section{DAFTAR PUSTAKA}

Amin, M.A. (2013). Menjadi guru profesional. Bandung: Nuansa Cendekia. Arsyad, A. (2014). Media pembelajaran. Jakarta: PT. Rajagrafindo Persada.

Asmadji, H. (2013). Penggunaan media belajar power point untuk meningkatkan hasil belajar ipa materi pesawat sederhana siswa kelas VC sdn Ketabang I Surabaya. Jurnal Penelitian Pendidikan Guru Sekolah Dasar, 1 (1), 1 - 14.

Daryanto. (2012). Media pembelajaran. Bandung: PT. Sarana Tutorial Nurani Sejahtera. Daryanto. (2016). Media pembelajaran. Yogyakarta: Gava media.

Elpira, N \& Ghufron, A. (2015). Pengaruh penggunaan media powerpoint terhadap minat dan hasil belajar ipa siswa kelas IV SD. Jurnal Inovasi Teknologi Pendidikan, 2 (1), $95-104$.

Hanifah, N. (2014). Memahami penelitian tindakan kelas(teori dan aplikasi). Bandung: UPI Press.

Musfiqon. (2012). Pengembangan media dan sumber belajar. Jakarta: Prestasi Pustakarya. 
Nurlatifah, A. (2015). Pengembangan media pembelajaran ipa berbasis Microsoft office power point interaktif pada siswa kelas IV sd negeri Ngrukeman Kasihan Bantul. Jurnal PGSD Indonesia, 1 (2).

Nursalim, M. (2013). Pengembangan media bimbingan dan konseling. Jakarta: Akademia.

Noprianti \& Syarifuddin. (2015). Pengaruh penerapan media slide power point terhadap hasil belajar peserta didik kelas III pada mata pelajaran ipa di madrasah ibtidaiyah ahliyah 2 Palembang. Jurnal Ilmiah PGMI, 1 (1), 1 - 29.

Rahmattullah, M. (2011). Pengaruh pemanfaatan media pembelajaran film animasi terhadap hasil belajar (studi eksperimen pada mata pelajaran ips siswa kelas vii smpn 6 Banjarmasin). Jurnal Penelitian Pendidikan, 1, 178 - 186.

Riskiawan, H.Y., Setyohadi, D.P.S., \& Arifianto, A.S. (2016). Pelatihan pengembangan media pembelajaran berbasis multimedia untuk meningkatkan kualitas dan kreativitas guru sma. Jurnal Pengabdian Masyarakat J-DINAMIKA, 1 (1), 48 - 52.

Surachman, E. (2016). Workshop pemanfaatan media pembelajaran sebagai upaya peningkatan efektifitas pembelajaran serta profesionalitas pendidik di smp negeri 194 Jakarta. Jurnal Sarwahita, 13 (2), 111 - 119.

Werdhiana, I.K., Wahyono, U. \& Miftah, M. (2020). Implementasi perangkat pembelajaran audio visual ipa berbasis energy surya untuk meningkatkan motivasi dan minat belajar siswa smp di daerah tertinggal. Jurnal Pendidika Fisikan Taduloko Online (JPFT), 8 (1), 78 - 86.

Widodo, W. (2016). Wujud kenyamanan belajar siswa, pembelajaran menyenangkan, dan pembelajaran bermakna di sekolah dasar. Ar-Risalah, 18 (2), 22 - 37. 